\title{
Penurunan Luaran Neurodevelopmental pada Sepsis Neonatal terjadi melalui Peningkatan IL- 6 dan bukan TNF- $\alpha$
}

\section{Decreasing Neurodevelopmental Outcome on Sepsis Neonatal Occurs through Increasing IL- 6 Level but not TNF- $\alpha$}

\author{
Rahmawati Aminingrum ${ }^{1}$, Ariani $^{1}, M$ Istiadjid $_{E S^{2}}$ \\ ${ }^{1}$ Laboratorium Ilmu Kesehatan Anak RSUD Dr. Saiful Anwar Malang \\ ${ }^{2}$ Laboratorium IImu Bedah RSUD Dr. Saiful Anwar Malang
}

\begin{abstract}
ABSTRAK
Bayi yang mengalami gangguan pada masa prenatal, natal dan paska natal mempunyai risiko tinggi untuk mendapatkan hambatan tumbuh kembang secara optimal dibandingkan bayi lainnya. IL- 6 dan TNF- $\alpha$ merupakan salah satu sitokin yang diproduksi saat terjadi sepsis dan mempunyai peranan pada perkembangan otak sebagai sinyal proinflamasi. Tujuan penelitian ini adalah untuk mengetahui pengaruh sepsis terhadap luaran neurodevelopmental, melalui peningkatan kadar IL- 6 dan TNF $\alpha$. Dua puluh neonatus yang memenuhi kriteria sepsis pada ruang perinatologi RSSA dimasukkan dalam subjek penelitian, diukur kadar IL- 6 dan TNF- $\alpha$ saat sepsis neonatal dengan menggunakan metode ELISA, dan dinilai perkembangannya pada usia 9 bulan dengan menggunakan Bayley 3. Analisis data diolah dengan menggunakan PLS untuk menentukan pengaruh sepsis neonatal terhadap luaran neurodevelopmental. Hasil penelitian menunjukkan peningkatan IL-6 dan TNF- $\alpha$ pada sepsi dan penurunan luaran neurodevelopmental usia 9 bulan terutama pada aspek kognitif diikuti motorik, dan bahasa, namun tidak didapatkan pengaruh bermakna pada peningkatan TNF- $\alpha$ dengan luaran neurodevelopmental. Dapat disimpulkan bahwa sepsis neonatal dapat berpengaruh pada luaran neurodevelopmental usia 9 bulan melalui peningkatan IL- 6 dan bukan TNF- $\alpha$.
\end{abstract}

Kata Kunci: IL-6, neonatal sepsis, neurodevelopmental outcome, TNF- $\alpha$

\section{ABSTRACT}

Infants who experience disruption during prenatal, natal, and post-natal have higher risk to get impairment on optimal growth and development than other babies. IL-6 and TNF- $\alpha$ are cytokines produced during sepsis and have a role in brain development as proinflammatory signals. The purpose of this study is to determine the effect of sepsis on neurodevelopmental outcomes through increasing levels of IL-6 and TNF- $\alpha$. Twenty neonates who meet sepsis criteria in perinatology ward at Saiful Anwar Hospital Malang were include as the study subjects and were measured in terms of levels of IL-6 and TNF- $\alpha$ at neonatal sepsis using ELISA method, and were assessed on its development at the age of 9 months using Bayley 3. Data analysis is processed by using PLS to determine the influence of neonatal sepsis on neurodevelopmental outcomes. The results show an increase in IL-6 and TNF- $\alpha$ in the sepsis and a decrease in neurodevelopmental outcome in those 9 month old babies especially on cognitive aspect followed by movement, and language, but do not show any significant influence on the increase of TNF- $\alpha$ with neurodevelopmental outcomes. It can be concluded that neonatal sepsis can affect the neurodevelopmental outcomes of 9 months of age through increased IL-6 but not TNF- $\alpha$.

Keywords: IL-6, neonatal sepsis, neurodevelopmental outcome, TNF- $\alpha$

Jurnal Kedokteran Brawijaya, Vol. 28, No. 4, Agustus 2015; Korespondensi: Rahmawati Aminingrum. Laboratorium Ilmu Kesehatan Anak Rumah Sakit Umum Daerah Dr. Saiful Anwar Malang, Jl. Jaksa Agung Suprapto No. 2 Malang Tel. (0341) 366242 Email: r.aminingrum@gmail.com 


\section{PENDAHULUAN}

Sepsis neonatal, sebagai salah satu permasalahan yang masih banyak dialami di negara berkembang merupakan salah satu faktor yang dapat menyebabkan hambatan tumbuh kembang bayi. Insiden infeksi neonatal di rumah sakit rujukan di Indonesia mencapai 8,76\%-30,29\% dengan angka kematian 11,56\%-49,9\%. Insiden sepsis neonatal di rumah sakit rujukan di Indonesia mencapai 1,5\%-3,72\% dengan angka kematian 37,09\%-80\% (1). Data di Rumah Sakit Umum Daerah (RSUD) Dr. Saiful Anwar Malang, menunjukkan pada tahun 2011, terdapat 274 bayi di bangsal neonatologi yang dirawat dengan sepsis, dan $41,6 \%$ diantaranya merupakan bayi cukup bulan.

Pada beberapa tahun terakhir, kemokin dan sitokin proinflamasi seperti tumor necrosis factor-alpha (TNF- $\alpha$ ), interleukin-6 (IL-6), IL-8 and pro-calcitonin (PCT) telah dikenalkan sebagai petandaawal pada bayi yang mengalami infeksi. Interleukin-6 diproduksi oleh monosit, sel endotel, dan fibroblas. Konsentrasi IL-6 meningkat secara cepat pada bakteremia, tetapi waktu paruhnya pendek. Penelitian sebelumnya menunjukkan bahwa IL-6 merupakan metode yang cepat, valid non invasif untuk mendiagnosis sepsis neonatal (2).

Tumor necrosis factor a merupakan sitokin proinflamasi yang penting dalam patogenesis sepsis dan syok septik, berperan dalam menstimulasi produksi IL-6 sertamempunyai aksi biologis yang luas pada berbagai tipe sel target, pada sel imun maupun sel non imun. Neonatus dengan infeksi onset dini mempunyai konsentrasi TNF $\alpha$ lebih tinggi dibanding yang tidak terinfeksi $(3,4)$. Interleukin-6 dan TNF- $\alpha$, keduanya diketahui mempunyai peranan pada perkembangan otak, dimana sebagai sinyal proinflamasi, TNF- $\alpha$ dapat menyebabkan perkembangan kematian sel, dan IL-6 juga menyebabkan gliosis reaktif melalui aktivasi mikroglia atau astrosit sehingga menyebabkan terjadinya astrositosis dan keterlambatan mielinisasi pada kerusakan materi putih pada bayi sangat premature (5-8).

Beberapa penelitian mencoba menghubungkan sepsis dengan luaran neurodevelopmental pada neonatus prematur. Mwaniki et al melakukan analisis terhadap 153 penelitian, dengan temuan bahwa sepsis pada bayi premature, $49 \%$ mengalami gangguan neurodevelopmental (9). Kulak et al pada studi retrospektifnya menunjukkan bahwa bayi septikemia berisiko palsi serebral 3,59 kali lipat (10). Schlapbach et al menunjukkan bahwa gangguan neurodevelopmental pada bayi sepsis 1,85 kali lipat (11). Vohr et al juga menunjukkan melalui penelitian secara kohort bahwa sepsis berhubungan dengan kejadian menurunnya indeks perkembangan psikomotor (12).

Penilaian perkembangan yang baku penting untuk mendeteksi awal keterlambatan perkembangan pada anak. Selama ini, Bayley III Scales of Infant Development paling banyak digunakan. Bayley III menilai wilayah kognitif, motorik, bahasa.

Sejauh pengetahuan peneliti masih belum didapatkan penelitian yang mengaitkan sepsis dan luaran neurodevelopmental pada neonatus cukup bulan. Penelitian serupa dilakukan pada neonatus prematur lahir rendah atau sangat rendah. Neonatus merupakan salah satu kelompok berisiko terhadap infeksi dan komplikasinya karena sistem imun neonatus yang masih belum sempurna (13). Tujuan penelitian ini adalah untuk mengetahui pengaruh luaran neurodevelopmental dari bayi dengan sepsis neonatal, melalui peningkatan kadar IL6 dan TNF $\alpha$.

\section{METODE}

Penelitian ini menggunakan rancangan studi cohort yang berlangsung selama 9 bulan. Penelitian inidilakukan di bagian Neonatologi Rumah Sakit Umum Daerah (RSUD) Dr. Saiful Anwar Malang, Poli Tumbuh kembang anak dan Laboratorium Biokimia Fakultas Kedokteran Universitas Brawijaya Malang dengan pengambilan sampel secara consecutive sampling. Kriteria inklusi yang digunakan meliputi neonatus aterm yang sesuai dengan kriteria sepsis, dan keluarga penderita mengijinkan bayinya diikutsertakan dalam penelitian setelah diberi penjelasan (informed consent) sebelumnya. Bayi yang memiliki kelainan bawaan, mendapat transfusi darah, neonatus dengan sepsis berat (gangguan sistem organ multipel) pada saat awal perawatan dikeluarkan dari subjek penelitian. Jika sampel darah lisis, pasien meninggal sebelum pengamatan akhir, sakit berat pada sistem saraf sebelum dilakukan pemeriksaan, dan tidak dapat terlacak atau tidak datang saat pemeriksaan dinyatakan drop out daripenelitian.

Sepsis neonatal adalah sepsis yang terjadi pada periode neonatus, yaitu yang berusia kurang dari 1 bulan. Early onset sepsis: sepsis yang terjadi dalam waktu kurang dari 72 jam, late onset sepsis: sepsis yang terjadi lebih dari 72 jam. Disebut sepsis jika didapatkan tanda SIRS disertai bukti adanya infeksi dengan kriteria: 1) temperatur $>38,5$ atau $<36^{\circ} \mathrm{C}$; 2) takikardia, denyut jantung $>2$ SD diatas batas normal usia, tanpa ada stimulus eksternal; 3)frekuensi nafas >2SD diatas batas normal usia; 4) leukosit meningkat atau menurun atau $>10 \%$ netrofil imatur (14).

Kadar IL-6, TNF $\alpha$ adalah merupakan sitokin pro inflamasi yang diperiksa bila telah terjadi tanda SIRS. Kadar IL-6 dan TNF- $\alpha$ diperiksa dengan cara ELISA menggunakan kit Human IL-6 dan TNF- $\alpha$ immunoassay dalam satuan $\mathrm{pg} / \mathrm{ml}$. Luaran neurodevelopmental dinilai pada usia 9 bulan, dengan menggunakan Bayley-III Scale of Infant and Toddler development, third edition. Penilaian dilakukan secara langsung pada anak terhadap wilayah kognitif, bahasa, dan motorik, oleh minimal 2 pemeriksa. Skala yang dipakai adalah skor komposit.

\section{HASIL}

Jumlah sampel yang didapatkan dalam proses penelitian adalah sebanyak 35 sampel yang terdiri atas bayi dengan sepsis sebanyak 20 neonatus dengan sepsis dan sebanyak 15 bayi sebagai kontrol. Ditinjau dari jenis kelamin dan proses persalinan tidak terdapat perbedaan dalam prosentase antara sepsis neonatal dengan kontrol. Resusitasi dan PROM (premature rupture of the membrane) pada kelompok sepsis lebih tinggi daripada kelompok kontrol.

Tabel 1. Karakteristik subjek penelitian

\begin{tabular}{lrr}
\hline \multirow{2}{*}{ Variabel } & \multicolumn{2}{c}{ Kelompok } \\
\cline { 2 - 3 } & Kontrol $\mathbf{n = 1 5}$ & Sepsis $\mathbf{n = 2 0}$ \\
\hline Jenis kelamin & 10 & 14 \\
-Laki-Laki & 5 & 6 \\
-Perempuan & & \\
\hline
\end{tabular}


Tabel 1. Karakteristik subjek penelitian (Lanjutan)

\begin{tabular}{lrr}
\hline \multirow{2}{*}{ Variabel } & \multicolumn{2}{c}{ Kelompok } \\
\cline { 2 - 3 } Resusitasi & Kontrol $\mathbf{n = 1 5}$ & Sepsis $\mathbf{n = 2 0}$ \\
-Ya & 1 & 12 \\
-Tidak & 14 & 8 \\
PROM & & \\
-Ya & 4 & 14 \\
-Tidak & 11 & 6 \\
Persalinan & & \\
-Normal & & \\
-SC & 8 & 8 \\
- Vacum & 7 & 11 \\
& 0 & 1
\end{tabular}

Keterangan: $\mathrm{PROM}=$ premature rupture of the membrane, $\mathrm{SC}=$ Sectio Caesarea

Data menunjukkan pada aspek usia kehamilan ibu, berat badan saat lahir, kadar $\mathrm{Hb}$, tidak terdapat perbedaan antara bayi sepsis dengan kontrol demikian juga kadar leukosit (Tabel 2).

Tabel 2. Gambaran luaran persalinan

\begin{tabular}{lrr}
\hline \multicolumn{1}{c}{ Variabel } & \multicolumn{2}{c}{ Kelompok } \\
\cline { 2 - 3 } & \multicolumn{1}{c}{ Kontrol } & \multicolumn{1}{c}{ Sepsis } \\
\hline Usia Kehamilan (minggu) & $38,27 \pm 1,1$ & $38,55 \pm 1,43$ \\
BB Lahir (gram) & $3223,73 \pm 384,7$ & $3083 \pm 561,68$ \\
Kadar HB (g/dL) & $13,91 \pm 2,32$ & $14,53 \pm 2,56$ \\
Kadar Leukosit $\left(/ \mathrm{mm}^{3}\right)$ & $20.159,93 \pm 10910,55$ & $16.523 \pm 11016,39$ \\
\hline
\end{tabular}

Tabel 3 menunjukkan bahwa rata-rata TNF- $\alpha$ pada bayi sepsis $(135,01 \pm 140,32)$ lebih tinggi secara bermakna $(p=0,002)$ dibandingkan kelompok kontrol $(55,71 \pm 89,64)$. Temuan serupa juga didapatkan pada kadar IL-6, yang jauh lebih tinggi secara bermakna $(p=0,007)$ pada bayi sepsis $(123,32 \pm 256,95)$ dibandingkan kelompok kontrol $(10,71 \pm 5,44)$. Standar deviasi pada dalam kedua aspek penilaian pada masing-masing kelompok tersebut tinggi karena hamper sama dengan nilai rata-ratanya, bahkan pada kelompok bayi sepsis didapatkan standar deviasi lebih tinggi daripada rata-rata yang menunjukkan besarnya variasi hasil ukur yang besar.

Tabel 3. Hasil uji Mann Whitney perbandingan tnf- $\alpha$ dan il-6 pada kelompok sepsis dan kontrol

\begin{tabular}{lrrr}
\hline \multirow{2}{*}{ Variabel } & \multicolumn{2}{c}{ Kelompok } & \multirow{2}{*}{ p-value } \\
\cline { 2 - 3 } & \multicolumn{1}{c}{ Kontrol } & Sepsis & \\
\hline TNF-Alpha & $55,71 \pm 89,64$ & $135,01 \pm 140,32$ & 0,002 \\
IL-6 & $10,71 \pm 5,44$ & $123,32 \pm 256,95$ & 0,007 \\
\hline
\end{tabular}

Data pada Tabel 4 menunjukkan bahwa terdapat perbedaan yang signifikan perkembangan kognitif, motorik, dan bahasa antara bayi sepsis dengan kontrol. Nilai rata-rata skala kognitif dan komposit pada bayi sepsis lebih rendah daripada kelompok kontrol.
Tabel 4. Pengujian perbandingan luaran neurodevelopmental

\begin{tabular}{lrrr}
\hline \multirow{2}{*}{ Variabel } & \multicolumn{2}{c}{ Kelompok } & \multirow{2}{*}{ p-value } \\
\cline { 2 - 3 } & \multicolumn{1}{c}{ Kontrol } & \multicolumn{1}{c}{ Sepsis } & \\
\hline Cognitive Scale & $9,33 \pm 0,62$ & $7,8 \pm 2,28$ & 0,034 \\
Cognitive Composite & $96,67 \pm 3,09$ & $89 \pm 11,42$ & 0,034 \\
Language Scale & $18,27 \pm 1,83$ & $15,75 \pm 3,08$ & 0,008 \\
Language Composite & $95 \pm 5,15$ & $87,9 \pm 8,88$ & 0,008 \\
Motoric Scale & $18,2 \pm 1,97$ & $16,7 \pm 1,98$ & 0,006 \\
Motoric Composite & $96 \pm 2,93$ & $90,4 \pm 5,3$ & 0,001 \\
\hline
\end{tabular}

Pengujian hipotesis dalam penelitian ini dilakukan untuk menguji pengaruh sepsis neonatal dengan luaran neurodevelopmental melalui peningkatan kadar TNF- $\alpha$ dan IL-6. Variabel luaran neurodevelopmental merupakan variabel yang terbentuk oleh aspek kognitif, bahasa, dan motorik secara formatif. Kadar TNF- $\alpha$ dan IL- 6 bertindak sebagai variabel intervening. Oleh karena itu, pengujian dilakukan dengan menggunakan PLS (Partial least square), dengan pengujian Inner Model, yang dilakukan untuk menguji pengaruh sepsis neonatal terhadap luaran neurodevelopmental melalui peningkatan kadar TNF- $\alpha$ dan IL-6.

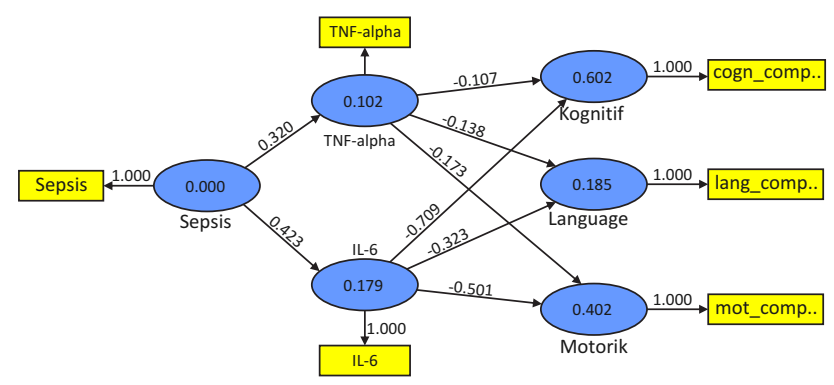

Gambar 1. Gambar hasil pengujian hipotesis inner model

Berdasarkan pada hasil pengujian hipotesis, terdapat pengaruh posistif yang signifikan antara sepsis terhadap TNF- $\alpha(0,320, t=3,893)$ dan IL-6 $(0,423, t=8,834)$. Koefisien path bernilai positif menunjukkan bahwa bayi sepsis memiliki TNF- $\alpha$ dan IL- 6 yang lebih tinggi daripada bayi normal. Dapat disimpulkan sepsis neonatal dapat meningkatkan kadar TNF- $\alpha$ dan IL-6.

Pengujian pengaruh TNF- $\alpha$ terhadap Iuaran neurodevelopmental yang terdiri dari aspek kognitif, bahasa, dan motorik menunjukkan bahwa TNF- $\alpha$ tidak memberikan pengaruh yang signifikan. Koefisien path bernilai negatif menunjukkan bahwa TNF- $\alpha$ memberikan negatif terhadap perkembangan motorik, bahasa, dan kognitif, tetapi tidak menunjukkan pengaruh signifikan. Hasil uji menunjukkan bahwa IL-6 memberikan pengaruh negatif yang signifikan terhadap semua aspek luaran neurodevelopmental (motorik, bahasa, dan kognitif). Semakin tinggi kadar IL-6, berdampak pada penurunan dan keterlambatan perkembangan kognitif, bahasa, dan motorik bayi neonatus. Ditinjau dari besaran koefisien path, didapatkan bahwa koefisien path paling besar berada pada jalur pengaruh IL- 6 terhadap aspek kognitif. Artinya, IL-6 lebih banyak berpengaruh terhadap perkembangan kognitif. 
Tabel 5. Pengujian hipotesis inner model

\begin{tabular}{lcrr}
\hline \multicolumn{1}{c}{ Jalur Pengaruh } & $\begin{array}{c}\text { Path } \\
\text { Coefficient }\end{array}$ & T-Statistic & Keterangan \\
\hline Sepsis -> IL-6 & 0,423 & 8834 & Signifikan \\
Sepsis -> TNF-alpha & 0,320 & 3,893 & Signifikan \\
TNF-alpha -> Kognitif & $-0,107$ & 1,420 & Tidak Signifikan \\
TNF-alpha -> bahasa & -0138 & 1,355 & Tidak Signifikan \\
TNF-alpha -> Motorik & $-0,173$ & 1,355 & Tidak Signifikan \\
IL-6 -> Kognitif & $-0,709$ & 9,046 & Signifikan \\
IL-6 -> bahasa & $-0,323$ & 4,552 & Signifikan \\
IL_6 _> Motorik & 0,501 & 3,980 & Signifikan \\
\hline
\end{tabular}

Secara keseluruhan hasil analisis jalur menunjukkan bahwa kondisi sepsis pada neonatal akan meningkatkan kadar TNF- $\alpha$ dan IL-6 dan peningkatan IL-6 (bukan TNF- $\alpha$ ) akan memberikan dampak pada penurunan luaran neurodevelopmental dengan pengaruh terbesar pada aspek perkembangan kognitif. Hal ini membuktikan bahwa kondisi sepsis akan memberikan penurunan luaran neurodevelopmental melalui peningkatan IL- 6 dan bukan TNF- $\alpha$. Hasil uji total effect juga menunjukkan pengaruh negatif yang signifikan sepsis neonatal terhadap luaran neurodevelopmental dengan besaran pengaruh tertinggi pada aspek kognitif $(-0,334)$ diikuti aspek motorik $(-0,267)$ kemudian bahasa $(-0,181)$ (Tabel 6). Atau dengan kata lain, kejadian sepsis neonatal berdampak pada penurunan luaran neurodevelopmental.

Tabel 6. Pengujian total effect sepsis neonatal

\begin{tabular}{lrrr}
\hline Jalur Pengaruh & Path Coefficient & T-Statistic & Keterangan \\
\hline Sepsis -> Kognitif & $-0,334$ & 6,733 & Signifikan \\
Sepsis -> Bahasa & $-0,181$ & 4,125 & Signifikan \\
Sepsis -> Motorik & $-0,267$ & 5,634 & Signifikan \\
\hline
\end{tabular}

\section{DISKUSI}

Dari total 43 sampel yang kami kumpulkan, ada 35 sampel yang berhasil kami kumpulkan data tumbuh kembangnya, 8 sampel drop out, karena 3 pasien meninggal, 1 pasien mengalami sakit berat dengan didapatkan perdarahan intra kranial dan hidrosefalus obstruktif saat usia 1,5 bulan, dan 4 pasien sebagai kasus yang tidak dapat terlacak. Karakteristik awal kedua kelompok sampel tidak berbeda dari usia kehamilan, cara persalinan, dan pengambilan sampel dilakukan pada instansi yang sama, yaitu RSUD Dr. Saiful Anwar, sehingga dapat mengurangi bias penelitian.

Sebagian besar subjek dengan sepsis neonatal membutuhkan langkah awal resusitasi saat persalinan awal, yaitu 34,3\%, dan lahir dari ibu dengan PROM sebesar $40 \%$. Hal inilah yang mungkin dapat meningkatkan risiko terjadinya sepsis neonatal pada subjek, dengan sebaran EOS sebesar 37,1\% dari total subjek penelitian.

Karakteristik subjek yang ditunjukkan dalam laboratorum $\mathrm{Hb}$ dan leukosit juga tidak menunjukkan perbedaan bermakna antara sampel dan kontrol, yang diambil bersamaan dengan pengambilan sampel darah. Leukosit pada kontrol tampak lebih tinggi secara angka dibanding dengan leukosit pada subjek sepsis. Hal ini dikarenakan rentang normal nilai leukosit pada bayi baru lahir dapat ditoleransi sampai dengan 24.000, Disamping itu, jika dilihat lebih lanjut, leukosit pada subjek sepsis beberapa menunjukkan ke arah leukopenia, yang dapat merupakan penanda adanya infeksi oleh kuman gram negatif, seperti yang ditunjukkan oleh kultur darah subjek.

Sebaran data hasil penelitian yang berupa kadar sitokin IL6 dan TNF- $\alpha$ ini tidak normal dengan range angka yang sangat lebar.Hal ini menunjukkan bahwa variabilitas/keragaman IL-6 pada kedua kelompok tersebut sangat tinggi. Salah satu faktor mungkin karena spektrum sepsis yang dimasukkan dalam penelitian terlalu lebar, dari bayi yang secara klinis terbukti sepsis, hingga sepsis yang cukup berat yang sudah mulai mengalami disfungsi organ, selama tidak mengalami kondisi gagal nafas, dan ancaman kematian masih tetap dimasukkan ke dalam penelitian ini.

Dari uji dengan Mann Whitney ini didapatkan peningkatan signifikan kadar IL-6 dan TNF- $\alpha$ pada subjek dengan sepsis neonatal dibanding kontrol dengan $p$ value 0,002 dan 0,007 , walaupun didapatkan standard deviasi yang sangat tinggi. Hal ini senada dengan penelitian-penelitian sebelumnya, yang menunjukkan peningkatan kedua sitokin tersebut pada bayi sepsis, salah satunya seperti yang dilakukan oleh Silviera dan Procianoy, 2003, bahwa IL6 plasma meningkat pada kedua kondisi sepsis dan asfiksia, sedangkan TNF- $\alpha$ hanya meningkat pada sepsis (15).

Dari pengujian terhadap luaran neurodevelopmental, dibandingkan dengan subjek sepsis dan kontrol, tampak berbeda secara signifikan terhadap tiga aspek yang diteliti, baik perkembangan kognitif, bahasa, dan motorik, menunjukkan bahwa luaran neurodevelopmental bayi sepsis lebih lambat daripada bayi normal, meskipun tidak ada yang mengalami keterlambatan sedang-berat.

Hasil luaran neurodevelopmental sepsis neonatal ini berbeda dengan berbagai penelitian sebelumnya yang dilakukan pada sepsis neonatal bayi prematur atau berat badan lahir sangat rendah. Pada penelitian terdahulu didapatkan perbedaan signifikan antara bayi prematur dan BBLR yang mengalami sepsis dan tidak, dan beberapa mengalami sekuel yang berat, seperti yang telah ditunjukkan oleh penelitian yang dilakukan di Swiss secara multisenter, dari 641 bayi dengan usia kehamilan 24-27 minggu, $136(25 \%)$ terbukti sepsis, $169(31 \%)$ suspek sepsis. Penelitian tersebut juga menemukan bahwa palsi serebral terjadi pada $14(10 \%)$ pasien yang terbukti sepsis, dibandingkan dengan bayi yang tidak terbukti infeksi, OR sebesar 2,9(95\% CI 1,22-6,89). Gangguan neurodevelopmental terjadi pada 46 bayi yang terbukti sepsis, dengan OR 1,85(95\% Cl 1,12-3,05), dibandingkan dengan yang tidak terinfeksi (11). Senada dengan penelitian yang dilakukan oleh Stoll et al, pada bayi dengan berat bayi lahir sangat rendah, bayi yang tidak mengalami infeksi akan mempunyai luaran neurodevelopmental yang berbeda dibanding bayi yang mengalami infeksi (16).

Bayi dengan sepsis mempunyai peningkatan insiden palsi serebral dan abnormalitas white matter (17). Dari penelitian pada hewan coba yang dilakukan oleh Vilela et al yang menilai efek sepsis pada perubahan mikrovaskuler otak, disebutkan bahwa selama sepsis, produksi sitokin dan kemokin otak pada fase awal berperan dalam disfungsi 
dari SSP dan perubahan permiabilitas sawar darah otak. Dan sepsis tidak hanya berhubungan dengan disfungsi otak akut, tetapi dapat juga menyebabkan defisit kognitif jangka panjang (18).

Belum adanya patokan baku yang dipergunakan pada Bayley untuk menentukan cut-off dalam penentuan derajat keterlambatan, menimbulkan permasalahan dalam mengelompokkan hasil penelitian berdasar derajat keterlambatan, ringan, sedang, dan berat. Bayley dalam Bayley III menetapkan mean 10 dan standard deviasi 3 terhadap skor skala masing masing aspek (19). Berdasar pengamatan Bayley dengan skor skala maupun skor komposit, walaupun juga didapatkan perbedaan dari nilai p secara statistik yang menunjukkan bahwa kelompok sepsis dengan kontrol, tidak ada dari ketiga aspek yang dinilai yang didapatkan mean skor komposit $<85$, yang dapat diartikan sebagai keterlambatan derajat sedang sampai berat. Patokan penilaian keterlambatan dalam Bayley III ini memakai patokan skor < 85, karena berdasar penelitian yang dilakukan oleh Johnson et al. skor kognitif dan bahasa $<85$ ekuivalen dengan $\mathrm{MDI}<70$ Bayley II pada keterlambatan sedang-berat (20).

Hipotesis penelitian ini adalah terdapat pengaruh sepsis neonatal dengan luaran neurodevelopmental melalui peningkatan kadar IL- 6 dan TNF- $\alpha$, sebagai variable mediasi. Untuk membuktikannya telah dilakukan uji hipotesis dengan menggunakan Partial Least Square dengan inner model, dan didapatkan hasil yang bermakna, bahwa sepsis dapat memberikan pengaruh pada peningkatan IL- 6 dan TNF- $\alpha$ dan peningkatan IL-6 memberikan pengaruh negative yang signifikan tehadap luaran neurodevelopmental sedangkan tidak.

TNF- $\alpha$ sebagai variabel mediasi berpengaruh negatif pada aspek kognitif, bahasa, dan motorik secara namun tidak pengaruh signifikan. Hasil ini sedikit berbeda dengan penelitian yang dilakukan oleh Ondine et al yang melakukan observasi perkembangan intelektual anak dalam hubungannya dengan kadar sitokin darah umbilikal, bahwa peningkatan TNF- $\alpha$ berhubungan dengan penurunan odds ratio pada bayi premature, dan peningkatan odds ratio pada bayi KMK. Sebaliknya IL-6 terbukti sebagai variabel mediasi yang berpengaruh signifikan pada aspek kognitif, motorik, dan bahasa. Ini sejalan dengan penelitian yang dilakukan oleh Chiesa et al disebutkan bahwa terdapat hubungan signifikan antara peningkatan IL-6 bayi aterm dan Iuaran neurodevelopmental pada usia 2 tahun (21).

Penelitian yang memperlihatkan pengaruh peningkatan sitokin dengan luaran neurodevelopmental ini senada dengan penelitian yang dilakukan oleh Bartha et al yang menunjukkan peningkatan sitokin, termasuk IL-6 dan TNF$\alpha$ pada neonatus aterm yang mengalami ensefalopati berhubungan dengan perkembangan neurodevelopmental abnormal usia 30 bulan (22). Sitokin berperan pada jalur umum injuri sistem saraf pusat dimulai dari infeksi, meskipun patogenesis langsung belum sepenuhnya diketahui. Peningkatan protein inflamasi yang dibarengi dengan akumulasi netrofil pada area yang mengalami kerusakan, aktivasi mikroglia/ makrofag, limfosit dan astrosit, yang menetap selama beberapa hari setelah inflamasi. Sitokin juga menstimulasi mikroglia dan astrosit memproduksi sitokin, kemokin, nitrit oksida, asam amino eksitatori, siklooksigenase dan ROS, dimana dapat merugikan otak imatur karena meningkatkan kerentanan sel yang sedang maturasi. Sitokin juga menghambat diferensiasi dan proliferasi prekursor oligodendosit, yang mempengaruhi mielinisasi aktif dan dapat mengakibatkan injuri area white matter (22). Sitokin yang beredar dalam darah yang meningkat pada kondisi sepsis ini dapat memberikan pengaruh di otak dengan menembus sawar darah otak melalui beberapa mekanisme, termasuk dalam hal ini adalah transport aktif, melalui area yang bocor atau melalui aktivasi jalur neural (23).

Di samping IL- 6 dan TNF- $\alpha$, ada beberapa marker lain yang disinyalir meningkat pada sepsis, dan disinyalir juga dapat berperan pada perkembangan otak, seperti IL-1 $\beta$, IL-8, IFN- $\gamma$, yang karena keterbatasan penelitian ini, belum kami lakukan pemeriksaan.Pemilihan subjek dan kontrol yang tepat akan mengurangi tingginya variasi hasil, seperti pada penelitian ini. Jika akan dilakukan penelitian yang serupa di masa datang, dapat dilakukan seleksi yang lebih tepat untuk subjek dan kontrol, termasuk dalam hal pengerucutan kriteria inklusi sepsis yang akan dipilih, sebagai salah satu variabel yang dapat merancukan hasil.Pengendalian faktor perancu penting dalam penelitian ini, karena penelitian ini merupakan peneltian jangka panjang, banyak faktor yang dapat berpengaruh terhadap luaran neurodevelopmental bayi, diantaranya penyakit yang diderita selama masa pengamatan, yang dalam hal ini sudah dilakukan eksklusi pada pasien yang mengalami sakit berat yang melibatkan gangguan neurodevelopmental. Faktor yang lain adalah faktor gizi, faktor sosial, yaitu stimulasi yang diberikan dalam keluarga, tingkat pendidikan ibu, usia ibu, jumlah angota keluarga, siapa yang berperan sebagai pengasuh bayi di rumah.

Keterbatasan lain penelitian ini terletak pada penilaian luaran neurodevelopmental hanya dilakukan satu waktu oleh dua pemeriksa dalam waktu bersamaan, sehingga terkadang kondisi anak saat pemeriksaan yang tidak optimal, seperti mengantuk, rewel, dapat berpengaruh pada hasil. Hasil yang lebih baik dan lebih terpercaya harusnya dilakukan pemeriksaan oleh dua pemeriksa dan dalam waktu yang berbeda, sehingga benar dapat dilihat nilai aspek perkembangan tanpa dipengaruhi kondisi sesaat. Penelitian ini juga hanya menggunakan satu parameter usia untuk menentukan luaran neurodevelopmental, yaitu usia 9 bulan yang ditetapkan sebagai waktu penilaian, dan tidak menyertakan penilaian pada usia sebelumnya, sehingga tidak dapat diketahui sejak usia berapa bayi mulai mengalami tren keterlambatan neurodevelopmental. Hasil yang lebih baik jika selama penelitian melibatkan pengukuran Bayley III pada usia 3 bulan dan 6 bulan. Gangguan yang mungkin dapat terjadi selama masa periode emas perkembangan, masih dapat berlangsung sampai usia 2 tahun, sehingga tidak adanya keterlambatan pada periode 9 bulan belum menyingkirkan kemungkinan tidak adanya gangguan setelah anak melewati periode emas perkembangan. Sebagai kesimpulan, luaran neurodevelopmental pada sepsis neonatal dengan neonatus aterm lebih jelek dibanding dengan kontrol, terjadi melalui peningkatan kadar sitokin IL-6 dan bukan TNF- $\alpha$. 


\section{DAFTAR PUSTAKA}

1. Aminullah A, Gatot D, Kosim S, Rohsiswatmo R, Indarso F, dan Dharma RD. Penatalaksanaan Sepsis Neonatorum. Jakarta: Departemen Kesehatan RI; 2007.

2. Shahkar L, Keshtkar A, Mirfazeli A, Ahani A, and Roshandel G. The Role of IL-6 For Predicting Neonatal Sepsis: A Systematic Review and Meta Analisis. Iranian Journal of Pediatrics. 2011; 21(4): 411-417.

3. Mishra U, Jacobs S, Doyle L, and Garland S. Newer Approaches to the Diagnosis of Early Onset Neonatal Sepsis. Archives of Disease in Childhood. 2006; 91(3): 208-212.

4. Kocabaş E, Sarikçioğlu A, Aksaray N, Seydaoğlu G, Seyhun Y, and Yaman A. Role of Procalcitonin, CRP, IL6,IL-8, and TNF Alpha in the Diagnosis of Neonatal Sepsis. The Turkish Journal of Pediatric. 2007; 49(1): 720.

5. Wilson $\mathrm{CJ}$, Finch $\mathrm{CE}$, and Cohen HJ. Cytokine and Cognition-The Case a Head to Toe Inflammatory Paradigm. Journal of the American Geriatrics Society. 2002; 50(12): 2041-2056.

6. Berger I, Peleg O, and Ofek-Shlomai N. Inflammation and Early Brain Injury in Term and Preterm Infants. The Israel Medical Association Journal. 2012; 14(5): 318-323.

7. Huppi P, Sizonenko S, and Amato M. Lung Disease and Brain Development. Biology of the Neonate. 2006; 89(4): 284-297.

8. Deverman BE and Patterson PH. Cytokines and CNS Development. Neuron. 2009; 64(1):61-79.

9. Mwaniki MK, Atieno M, Lawn JE, and Newton CR. Long-Term Neurodevelopmental Outcomes after Intra Uterine and Neonatal Insults: A Systematic Review.The Lancet. 2012; 379(9814): 445-452.

10. Kulak W, Sobaniec W, Okurowska-Zawada B, Sienkiewicz D, and Paszko-Pater G. Antenatal, Intra Partum, and Neonatal Risk Factor for Cerebral Palsy in Children in Podlaskie Province. Journal of Polish Society of Child Neurology. 2009; 18: 19-24.

11. Schlapbach LJ, Aebischer M, Adams M, et al. Impact of Sepsis on Neurodevelopmental Outcome in a Swiss National Cohort of Extremely Premature Infants. Pediatrics. 2011; 128(2): e348-357.

12. Vohr BR, Wright LL, Poole WK, and McDonald SA. Neurodevelopmental Outcomes of Extremely Low
Birth Weight Infants <32 Weeks Gestation Between 1993 And 1998. Pediatrics. 2005; 116(3): 635-643.

13. Wynn J, Cornell TT, Wong HR, Shanley TP, and Wheeler DS. The Host Response to Sepsis and Developmental Impact. Pediatrics. 2010; 125(5): 1031-1041.

14. Goldstein B, Giroir B, Randolph A, and International Consensus Conference on Pediatric Sepsis. International Pediatric Sepsis Consensus Conference: Definitions for Sepsis and Organ Dysfunction in Pediatric. Pediatric Critical Care Medicine. 2005; 6(1): 2-8.

15. Silveira RC and Procianoy RS. Interleukin-6 and Tumor Necrosis Factor-Alpha Levels in Plasma and Cerebrospinal Fluid of Term Newborn Infants with Hypoxic-Ischemic Encephalopathy. Journal of Pediatrics. 2003; 143(5): 625-629.

16. Stoll BJ, Hansen NI, Adams-Chapman I, et al. Neurodevelopmental and Growth Impairment among Extremely Low Birth Weight Infants with Neonatal Infection. Journal of the American Medical Association. 2004; 292(19): 2357-2365.

17. Mallard C and Wang X. Infection-Induced Vulnerability of Perinatal Brain Injury. Neurology Research International. 2012; 2012: 1-6.

18. Comim CM, Vilela MC, Constantino LS, et al. Traffic of Leucocyte and Cytokine Up-Regulation in the Central Nervous System in Sepsis. Intensive Care Medicine. 2011 ; 37(4): 711-718.

19. Bayley N. Bayley Scales of Infant and Toddler Development. San Antonio, USA: PsychCorp; 2006.

20. Johnson S, Moore T, Marlow N. Using the Bayley III to Assess Neurodevelopmental Delay: Which Cut Off Should Be Used? Pediatric Research. 2014; 75(5): 670674.

21. Chiesa C, Pellegrini G, Panero A, et al. Umbilical Cord Interleukin-6 Levels are Elevated in Term Neonates with Perinatal Asphyxia. European Journal of Clinical Investigation. 2003; 33(4): 352-358.

22. Bartha Al, Foster-Barber A, Miller SP, et al. Neonatal Encephalopathy: Association of Cytokines with $M R$ Spectroscopy and Outcome. Pediatric Research. 2004; 56(6): 960-966.

23. Eskandari F, Webster JI, and Stenberg EM. Neural Immune Pathway and Their Connection to Inflammatory Disease. Arthritis Resarch \& Teraphy. 2003; 5(6): 251-256. 